\title{
AN AMERICAN IN KING HENRY'S COURT: ORSON WELLES' CHIMES AT MIDNIGHT
}

\author{
ROBERT HORTON
}

Seattle University

\begin{abstract}
Orson Welles, a boy from Kenosha, Wisconsin, was one of the most audacious Shakespearians who ever lived. He recited soliloquies as a child, wrote a book on the plays as a teenager, and at age 17 roamed across Ireland before brazenly (and successfully) presenting himself at the Abbey Theatre as a distinguished American actor. Welles also created three of the most ambitious Shakespeare films. As an American pretender, a colonial presuming to re-interpret the greatest British writer, Welles approached Shakespeare with a mix of bravado and insecurity. This paper explores how Welles' American nature informs these roles and, especially, his final Shakespeare film, Chimes at Midnight (1965). In this production, Welles plays Falstaff and is understandably identified with the role, but it could be argued that he speaks more directly through Prince Hal, whose anxiety about inheriting the throne might be reflected in the way an American Shakespearian seeks to be accepted by the British keepers of the text. The words of Hal's father, Henry IV - Uneasy lies the head that wears the crown - might apply to Welles' American-inflected depictions of kings and princes who do not entirely believe in their own royal agency. The tension between Welles' brashness and his fretfulness created some of the most memorable Shakespeare in the cinema.
\end{abstract}

Keywords: Orson Welles, American Shakespearians, anxiety, Falstaff, adaptation, selfportraiture, cinematic language

In 1933, seventeen-year-old Orson Welles was in the middle of the Atlantic Ocean, aboard a freighter called the Exermont, bound for Morocco and adventure. Orphaned, and having completed a somewhat avant-garde education that had allowed his ambitions in the theatre free rein-these involved productions of the classics for which the adolescent prodigy directed, designed sets and costumes, prepared publicity materials, and invariably acted the lead role-Welles had long since been intoxicated by Shakespeare. He was celebrated in local newspapers for his ability to recite as a child, alleged to have memorized King Lear at age seven (this one was specifically disavowed by 
Welles himself), and had mounted a conflation of Shakespeare's histories while at school, an ambitious work he called Winter of Our Discontent. At sixteen, during a previous solo journey to Europe, he had bluffed his way into playing the Ghost in the Gate Theatre's production of Hamlet in Dublin. Now, in 1933, the young man was off to knock around North Africa, but he had an assignment to do on the way.

His mentor, Roger Hill (one of several surrogate fathers to Welles), had proposed that they collaborate on a book. Hill was the schoolmaster at the Todd School for Boys in Woodstock, Illinois, where Orson Welles had bowled over his classmates and teachers alike. Hill felt they could produce a book together that would make Shakespeare more accessible to Americans, especially American schools; the book would convey "Some of the tricks we used at Todd to make the Elizabethan popular in the classroom as well as the stage (Callow Vol. One 127)." It would be called Everybody's Shakespeare, and Hill would turn over most of the writing duties and all of the artwork to his wunderkind former student. Welles labored over the manuscript during this Atlantic crossing. His letters from the ship to Hill are still boyish, but grand and theatrical as well. He wrote, "You'll find grotesqueries in my stage directions, repetitions and misfiring ... The mere presence of Shakespeare's script worries me. What right have I to give credulous and believing innocents an inflection for his mighty lines? Who am I to say that this one is "tender" and this one is said 'angrily' and this 'with a smile'? (wellesnet 1)"

That mix of feelings, from a teenage boy from Kenosha, Wisconsin, the American Midwest, shows Welles already expressing the peculiar blend of attitudes that would define his relationship to Shakespeare for many years. There is a kind of rhetorical loftiness in that letter, a grand tone pretending to be humble. But the insecurity sounds authentic as well, despite being couched in bluster and chutzpah, as the boy dares to speak authoritatively on this revered subject. In the early 1930s, despite periods of intense popularity for Shakespeare in the United States, the subject of Shakespeare was something an American might hesitate to comment on-or at least he would self-consciously measure himself against his English counterparts if he did presume to speak on the subject.

I would like to suggest that Welles' extraordinary career, first on stage and then in the cinema, maintained that mixed mind-set through his lifelong devotion to Shakespeare, and that this tension finds its full expression in his 1965 film Chimes at Midnight, which he adapted, directed, and in which he plays Falstaff. Looking at the film through this prism, we might consider two points: 1) That this pretender's anxiety emerges in the decidedly non-decorousI would almost say anti-English - style of the film itself, a style that has a kind of American muscle and speed. We will return to that later. And 2) that the same 
anxiety comes across in Welles' identification with the character of Prince Hal, the future King Henry $\mathrm{V}$.

This point is somewhat counter-intuitive, as observers of the film have long identified Welles with Falstaff, a character he cherished throughout his career and a role that clearly contains autobiographical resonance for him. But we will examine the way the ambivalent character traits Welles sees in Prince Hal might not be very far from those of an American pretender to the Shakespearian throne, a combination of modern New World brashness with an outsider's anxiety. And it is anxiety that defines Welles' three Shakespeare films.

Orson Welles' life has been exhaustively chronicled by a range of different biographers, so unusual is his life story. He took the New York theater by storm at age twenty, and was on the cover of Time magazine at 22-and that was a few months before he became internationally famous because of his hoax radio broadcast of The War of the Worlds, where the story of New Jersey being invaded by Martians was presented as a mock newscast and the USA panicked as a result. Shakespeare courses through this story of Welles' rise, including his voodoo setting of Macbeth with an all-black cast and a 1937 Julius Caesar set in the modern attire of fascist Europe. The project that he had been writing during the transatlantic voyage had been published, as Everybody's Shakespeare, and then re-published when his renown grew wide; he supervised radio adaptations of Shakespeare and recorded four plays for release as long-playing albums.

With his imposing figure and preternaturally deep, rumbling voice, Welles was born to play kings. But as Francois Truffaut observed, Welles showed "the fragility of great authority (Callow, Vol. One 319)." On film he played three large-rounded Shakespeare roles in projects he adapted and directed - one king, one general, and Falstaff, the lord of misrule and briefly a king in his play-acting with Prince Hal. In his 1948 film of Macbeth, Welles plays the title role, and appears to have taken to heart Macbeth's panicked words, "But now I am cabined, cribbed, confined, bound in/To saucy doubts and fears," and made them the operating principle for both his performance and the film's mise-en-scene. The film is full of cramped rooms and smoky air, a smothering series of dens in which Welles' king scuttles to and fro. Welles grasps the anxieties of the Scottish king in a close way.

In his 1952 film of Othello, Welles again plays the title role, in a film so fragmented and chockablock that it seems to be coming apart at the same rate Othello himself is. Welles' Othello is a heroic statue that disintegrates before our eyes, slipping off the screen in vertiginous or slanted camera angles, disappearing in the bric-a-brac of the set design, lost in the slashing, jagged editing - the latter both an expressive stylistic strategy but also a necessity, born of the film's haphazard production schedule, which had scenes (sometimes the same scene) shot in different times and countries before being spliced into a coherent whole. 
The two roles in Macbeth and Othello are suited to Welles as an actor. He deploys his stentorian voice to strong effect, but he always allows the fault lines to show. Welles' tireless biographer, the actor Simon Callow, suggests that Welles' power, "while undeniable, seems assumed, put on-like a false noseand thus vulnerable. It seems as if behind the king, there is a little boy rather desperately playing at being a king. Thus his portrayal of power comes to seem a critique of power: man, proud man, drest in a little brief authority (Vol. One 319)." (Callow alludes to a passage from Measure for Measure as he ends his observation.)

As for Falstaff, the role is another natural, not least because by the mid1960s Welles had grown into the role - not just in age but in his physical size, which was now enormous. As a director, he'd previously mounted stage productions of the history plays that included a Falstaff in Welles' teenage years; a physically complicated production of the histories in the late 1930s called Five Kings (a production that closed out of town before reaching New York); and a 1960 production in Belfast and Dublin — in that version he focused mostly on the two parts of Henry $I V$ while adding lines from other plays. He called the Irish production Chimes at Midnight, and it appears to have been a fairly bald attempt to prepare for a cinematic version, though this film took a few years to mount.

Welles put the film together in the same way he mounted other independently-financed films - partly by seducing potential backers, taking acting roles in largely bad films and plowing his fees into his own productions, and sheer bravado. His association with the role of Falstaff was only strengthened by these habits. According to Keith Baxter, the actor who played Prince Hal in the Irish stage production, Welles abruptly summoned him to Spain a few years after the theatrical show to re-create his role on film. Baxter was immediately swept into a meeting with one of the film's producers, who enthusiastically said he was pleased to meet the actor who would be playing Dr. Livesey in Treasure Island. When Baxter was alone with Welles he asked what the reference was. Welles explained that he'd gotten financing for Chimes at Midnight by assuring the backer that he would also direct Treasure Island and play Long John Silver, the two projects to film simultaneously (Chimes special features).

Welles got at least one shot of a pirate ship in a Spanish harbor before quietly dispensing with the pretense that he was there to do anything other than make Chimes at Midnight. I cite that story not for its own sake but to suggest why people so perpetually identified Welles with the rascal Falstaff; both actor and character were capable of huge lies, great appetite, high living, and a tendency not to pay their bills. Keith Baxter observed that "Falstaff needed to duck and dive and to scheme and to plan and always living on the edge of no money at all — but being adored. That's very much Welles (Callow Vol. Three 397)." This might explain Welles' frequently stated love for Falstaff, whom he 
called "the most completely good man in all drama (Naremore, 217)." He felt that Falstaff was not a clown, but a man acting like a clown to please his royal charge and surrogate son (Welles, Bogdanovich, 261).

So it is not surprising that Welles chased Falstaff all those years, nor that others saw him that way (Charlton Heston, his Touch of Evil star, urged Welles to play Falstaff - after the release of Chimes at Midnight, a measure of the film's failure to be properly distributed [Chimes special features]). Nor is it surprising that Welles gave perhaps his fullest and most beautiful film performance in the role. It is also true that Welles was among the most unabashedly autobiographical of filmmakers (even if he directed only two self-written original stories in film-Citizen Kane and Mr. Arkadin, the others being adaptations), and he had a tendency to spread his self-portraits through different characters in his films. In Chimes at Midnight we can see in Prince Hal a strong (if less obvious) point of projection for the filmmaker, and also a vessel in which we can begin to detect the anxiety of the impostor, the interloper, the American in King Henry's Court.

I don't suggest that Welles equals the prince in some exact way, but we may prick a few points of comparison that could explain the film's intensely mixed portrayal of the future Henry V. Prince and film director were both ordained for greatness from their youth, and repeatedly told so. While Hal wastes his youth in the company of the profligate Sir John Falstaff, Welles recklessly gobbled what he could of the theater, a disreputable profession for a gifted young man (and worse, he then turned his brilliant energies toward cinema, an even less respectable practice, and to some a great betrayal of his talent). Welles, like the prince, knew the reality of an unreachable father, although in his case his father was a rather Falstaffian figure, a bon vivant who traveled, kept mistresses, and drank to excess; Welles' surrogate fathers were wiser and calmer than Hal's. And to round off the idea, Welles, like Hal, was practiced at hiding his true face, and not just under false noses, as Callow observes, although there are many of those in Welles' career. (Kenneth Tynan made one of his most famous quips when remarking on the uncertain false nose Welles wore in Welles' ambitious stage production of Moby Dick: "Sir Laurence Olivier began his film of Hamlet with the statement that it was 'the tragedy of a man who could not make up his mind.' At one point Mr. Welles' new appendage started to leave its moorings, and Moby Dick nearly became the tragedy of a man who could not make up his nose [Callow Vol. Three 187]"). He was a salesman and a flatterer and, by youthful training, a magician, whose job it is to keep the audience guessing about how it is all done.

In Chimes at Midnight, Welles depicts Hal as a calculating personality, planning for the throne even as he ruins his reputation through foolish capering with Falstaff and their cronies. And yet he comes across as not a purely calculating idler, but as insecure himself, certainly in the first section of the 
film-Hal knows that his father usurped the throne, and that his own claims toward royal inheritance are dubious; he has done nothing to deserve the crown, and his behavior with Falstaff's crew appears to be an attempt to prove exactly that. His father the king says, "Uneasy lies the head that wears the crown," but as Welles sees Hal, in a more psychoanalytic age, that might be amended to "Unworthy lies the head that wears the crown."

Welles stages Hal's revelatory "Yet herein will I imitate the sun" speech not as a soliloquy but in the company of Falstaff. We see both men's faces, the Prince in the foreground, Falstaff smaller in the background of the shot, as the future king visually takes on a new stature as he shares his plan to eventually throw off his loose behavior in order that he be more warmly received as a prodigal son. Falstaff hears this; and this interpretation on Welles' part makes Hal's journey a kind of understood project between the two men-not that it lessens the effect of the eventual renunciation scene on Falstaff, as we will discuss. By including Falstaff in the scene, Welles perhaps makes Hal fairer to Falstaff-and yet it doesn't diminish the cruelty of Hal's strategy.

Welles is hard on Hal, and one other biographical connection on this point might suggest why. Welles' affection for Falstaff makes the film's climactic renunciation scene arguably the most emotionally-fraught moment in any film adaptation of Shakespeare. As the new King Henry V banishes Falstaff, and the former wastrel's shrewdness becomes apparent, Welles uses the power of the close-up - a tool he preferred to withhold for maximum impact (he once said the close-up could be undemocratic and unaesthetic [Callow Vol. One xii]) — and his own face as the tools of reinterpretation. Here Welles plays Falstaff's reaction not as devastation but initially as confusion that gives way to a sort of glowing pride: Welles's eyes fairly brim with Falstaff's love, which, as Welles interprets him, is stronger in Falstaff than pain. Only by reinterpreting Falstaff as the "only good man" to occupy a leading role in literature, as Welles claimed, could Welles reach this stirring conclusion.

This banishment had a personal history with Welles. As a teenager, he was warned by his surrogate fathers that the only way to help Welles' father to conquer his debilitating and embarrassing alcoholism was to stop seeing the father. So the 15-year-old Orson did exactly that, refusing his father's invitations to travel and cavort. A few months later, Welles' father died alone in a hotel room at age 58, and his son always said he felt the guilt of banishing his parent at that moment. In 1982, three years before his own death, Orson Welles wrote a magazine article that ended with his theatrical assertion that he had killed his father; he ended the piece with the words, "I'll try to write about that later," but he never did (Callow Vol. One 62).

As to the question of film style on our general thesis: Welles' fluid expression of film language gives us one way to support the argument that the film itself is an American's bold but anxious take on Shakespeare. For a start, he 
vigorously prunes the text. Most directors cut Shakespeare, but as early as Everybody's Shakespeare, Welles was espousing the wisdom of radically cutting and re-ordering lines and scenes, and one infers that some of this is the American impulse to keep things briskly moving along. Welles' admiration for Shakespeare was unbounded but by no means reverent, and it was laced perhaps with a little of the American impertinence that was caught by Henry David Thoreau in his famous put-down of an English literature, including Shakespeare, that was "essentially tame and civilized," and needing of some American wildness (Thoreau 577).

If Welles did not hesitate to re-shape the text, he still voiced an inferiority complex - to use the Freudian term that was popular in the 1960sabout tackling Shakespeare. When he anticipated the arrival of the fabled actor John Gielgud to the set of Chimes at Midnight (Gielgud's lofty, cool-headed Henry IV is a study in Shakespearian precision) he shared his nervousness with Keith Baxter. He told the young actor, "Do you think John will think me a fool? No actor can touch him in Shakespeare. I don't want him to think me just a trickster (Callow Volume Three 392)." This last comment showed Welles' sensitivity to criticism, as some observers of his directing-even in the rapturously received stage work of the 1930s - had wondered whether his talent was more for brilliant concepts and buoyant spectacle than for actual interpretation.

By the way, if Gielgud's beautiful voice represents the epitome of the English Shakespearian tradition, Michael Anderegg notes that Henry's voice is parodied, in an exact impersonation of Gielgud's unmistakable tenor, by Hal, Falstaff, and Hotspur, at various times in the film (133). Welles relishes this criticism of the royal authority as it applies to both the English ruling family and English theatrical royalty.

Welles seems to find soliloquies a theatrical convention, because those speeches are invariably delivered with another character listening (as with Hal's speech), or simply as conversational. In his book on Welles and Shakespeare Michael Anderegg thought it was Welles' "ambivalence toward rhetoric" (131) that led him to reject the monologue as a modus operandi; this jibes with the idea of Welles side-stepping the grand English theatrical style in favor of the intimate possibilities of cinema (some of the soliloquies in Welles' film of Macbeth are delivered in voiceover rather than declaimed).

In the language of cinema itself, in the style of the movie, Welles accounts himself an impatient $20^{\text {th }}$-century American. Having cut the text to the bone, he also paces the action with a frantic, headlong beat-especially at the Boar's Head Tavern or in the company of Hotspur. Welles was famous in his radio days and films such as Citizen Kane for his use of overlapping dialogue, and people have applauded this as a modern, realistic style of directing speech; but it is also the impulse of someone who fears being boring, someone who 
wants to get to the point and then get to the next thing. Applying this to Shakespeare-where the text is ostensibly the reason for being in front of this play-seems perverse at best, but Welles rushes the action, to create froth and frenzy everywhere except the King's frosty palace.

This notion is supported by the tilting angles and quick movements inside the tavern, a set built with forced perspective according to Welles' specifications. That speed might be Welles' American spirit, plunging ahead, even as it suits Falstaff's quick mode of discourse. Or it might be the speed of a magician shoving things along so that the spectators don't catch on to the trick. (When Welles was editing the film he kept cutting it back to the point where friends had to tell him to re-insert material, lest the story become impossible to follow.)

The film's most astonishing sequence is also the one most laced with deep skepticism and absurdist humor: the battle of Shrewsbury. Here Welles as director can be seen in contrast to Laurence Olivier, who parlayed his great success as an actor into work as a director of Shakespearian film. There had previously been some simmering rivalry between the American and the quintessential English man of the theater, at least on Welles' part; at the moment his very low-budget film of Macbeth had premiered to mixed reception and boxoffice failure, Olivier had directed and starred in a film of Hamlet that landed him on the cover of Life magazine in the United States and won four Oscars, including Best Actor. As though to twist the dagger, Welles' Othello was not released in U.S. theaters until 1955, when Olivier's Richard III was already gathering attention (Anderegg 37). There was even an uncomfortable disagreement at close quarters between the two, when Welles directed the first English-language production of Ionesco's Rhinoceros in London, with Olivier starring, and some weeks into production Olivier had to bar Welles from the rehearsal stage because the cast was fed up with their director's constant tinkering with stage business and line readings - an uncertainty that perhaps reveals some of Welles' anxiety.

For Chimes at Midnight, Welles directed a battle scene that is brutish and grimy; as it deteriorates, the cutting of the film becomes as violent as the fight itself, so that we become almost completely disoriented within the mayhem; soon the soldiers cannot be distinguished from each other, but are simply meat temporarily clad in armor, rolling around in the mud and excrement. It is a scathing sequence, as though to underline Falstaff's skeptical speech on "honour," and through the fighting we sometimes glimpse the fat comic figure of Falstaff in his diving-bell-like armor, like a Samuel Beckett character scurrying absurdly through this slaughterhouse.

The anti-heroic grimness of the sequence is perfectly in touch with the tenor of war scenes in 1960s films, even somewhat ahead of the curve. This is a post-WWII battle scene, in which honor is buried in the frantic cutting and the 
murk and the inability to tell one side from the other. In this, I wonder whether the American Welles is calling out the more decorous Shakespearian battle scene in the very English 1944 film version of Henry V, directed by and starring Olivier, a film made expressly as a rallying cry for a British public suffering through the war. Olivier's Battle of Agincourt is not entirely decorous, but it is relatively brief, fought under sunny skies, and rendered in bright Technicolor; the St. Crispin's Day speech still rings in our ears. Welles' scene is much more attuned to the era of Joseph Heller's novel Catch-22, published in 1961, and Bob Dylan's song "Masters of War," released in 1963. It almost certainly carries the influence of Kafka's literature of despair, which had become popular in the U.S. after WWII and had provided Welles with the material for the film he directed before Chimes at Midnight, a version of The Trial.

If Welles believed, as he sometimes stated, that his large American personality would not abide a well-mannered approach to Shakespeare, here he was proving it with a vengeance. If there is anything to the theory that Welles evinced some anxiety as a presumptuous American treading on sacred English turf, he might have been able to bury it in the mud of Shrewsbury. The battle is a nightmare, but it's the place where the director truly assumes his authority as an interpreter of Shakespeare, and it is a triumph.

\section{Works Cited}

Anderegg, Michael A. Orson Welles, Shakespeare, and Popular Culture. New York: Columbia University Press, 1999. Print.

Callow, Simon. Orson Welles Volume One: Road to Xanadu. New York: Penguin Books, 1997. Print.

Callow, Simon. Orson Welles Volume 2: Hello Americans. New York: Viking, 2006. Print.

Callow, Simon. Orson Welles Volume 3: One-Man Band. New York: Viking, 2015. Print.

Chimes at Midnight. Dir. Orson Welles. Perf. Orson Welles, Keith Baxter, John Gielgud. Peppercorn-Wormser Film Enterprises, 1965. DVD.

Dunn, Esther Cloudman. Shakespeare in America. New York: The Macmillan Co., 1939. Print.

McBride, Joseph. Orson Welles. New York: Da Capo Press, 1996. Print.

Naremore, James. The Magic World of Orson Welles. Dallas: Southern Methodist University Press, 1989. Print.

Shapiro, James, ed. Shakespeare in America: An Anthology from the Revolution to Now. New York: Library of America, 2016. Print.

Thoreau, Henry David. The Portable Thoreau. New York: Penguin Books; Revised Edition, 1964. Print.

Tynan, Kenneth. He That Plays the King: A View of the Theatre. London: Longmans Green, 1950. Print. 
Welles, Orson. Orson Welles on Shakespeare: The W.P.A. and Mercury Theatre Playscripts. New York: Routledge, 2001. Print.

Welles, Orson. "Orson Welles Writes the Introduction to Everybody's Shakespeare in the North Atlantic," Wellesnet, N.P.,September 23, 2007, Web, accessed October 15,2016

Welles, Orson, and Peter Bogdanovich. This Is Orson Welles. New York: Da Capo Press, 1998. Print. 